ISSN 2076-393X

www.mdpi.com/journal/vaccines

Review

\title{
Developing Combined HIV Vaccine Strategies for a Functional Cure
}

\author{
Alessandra Noto and Lydie Trautmann * \\ Vaccine and Gene Therapy Institute of Florida, Port Saint Lucie, Florida, FL 34987, USA \\ * Author to whom correspondence should be addressed; E-Mail: 1trautmann@vgtifl.org; \\ Tel.: +1-772-345-5671; Fax: +1-772-345-0625.
}

Received: 5 September 2013; in revised form: 8 October 2013 / Accepted: 12 October 2013 /

Published: 28 October 2013

\begin{abstract}
Increasing numbers of $\mathrm{HIV}$-infected individuals have access to potent antiretroviral drugs that control viral replication and decrease the risk of transmission. However, there is no cure for HIV and new strategies have to be developed to reach an eradication of the virus or a natural control of viral replication in the absence of drugs (functional cure). Therapeutic vaccines against HIV have been evaluated in many trials over the last 20 years and important knowledge has been gained from these trials. However, the major obstacle to HIV eradication is the persistence of latent proviral reservoirs. Different molecules are currently tested in ART-treated subjects to reactivate these latent reservoirs. Such anti-latency agents should be combined with a vaccination regimen in order to control or eradicate reactivated latently-infected cells. New in vitro assays should also be developed to assess the success of tested therapeutic vaccines by measuring the immune-mediated killing of replication-competent HIV reservoir cells. This review provides an overview of the current strategies to combine HIV vaccines with anti-latency agents that could act as adjuvant on the vaccine-induced immune response as well as new tools to assess the efficacy of these approaches.
\end{abstract}

Keywords: HIV; therapeutic vaccine; $\mathrm{CD}^{+} \mathrm{T}$ cells; reactivation of viral reservoirs; combination therapy; functional cure 


\section{Introduction}

Despite the undeniable success of antiretroviral therapy (ART) in limiting HIV replication, it has become increasingly evident that ART is not a long-term solution for HIV-infected individuals. Besides the deleterious side effects, ART does not eradicate HIV and does not optimally reconstitute the immune system [1,2]. Novel immunotherapeutic strategies that would induce the immune-mediated control of HIV replication in the absence of ART (also called "functional cure") are needed. However, tested vaccination strategies have so far shown limited success (reviewed in [3]). Immune mechanisms of HIV control are still unknown and need to be elucidated in order to help develop these therapeutic interventions. In individuals who naturally maintain undetectable viral load without ART, called elite controllers (ECs), the control of HIV replication in the absence of treatment has been primarily attributed to an effective adaptive immune response [4]. However, in most HIV-infected subjects, HIV-mediated immune damages (mainly $\mathrm{CD}^{+} \mathrm{T}$ cell depletion and chronic inflammation) lead to a dysfunctional immune response that is not restored by ART [1,5]. Moreover, viral control is only achieved by ART and treatment interruption results in a rapid return of viremia.

The major obstacle to HIV eradication is the persistence of latent proviral reservoirs that are not targeted by antiretroviral regimens [6-10]. Eradication strategy aims at the induction of viral replication in latently-infected cells and at the elimination of these reactivated cells by either direct cytolytic targeting or by immunotherapeutic intervention [11]. HIV-specific CD8 ${ }^{+}$cytotoxic $\mathrm{T}$ cells (CTLs) are important for the control of HIV replication in non-treated individuals but in subjects under ART their number is too low to kill the latent reservoirs. Recently, Dr. Siliciano's group showed that after in vitro expansion of $\mathrm{HIV}$-specific $\mathrm{CD}^{+} \mathrm{T}$ cells from ART-treated subjects, these cells were able to eliminate $\mathrm{HIV}$-infected $\mathrm{CD}^{+} \mathrm{T}$ cells [12]. This seminal study provided the rationale for new therapeutic strategies that combine agents that reactivate latently-infected $\mathrm{CD} 4^{+} \mathrm{T}$ cells with immune interventions that increase the numbers and function of HIV-specific CD8 ${ }^{+}$CTLs to clear HIV reservoirs in individuals on ART. However peptide-stimulated HIV-1-specific $\mathrm{CD}^{+} \mathrm{T}$ cells were used in this study, which might not reflect in vivo approaches. In addition, in this study only one histone deacetylase inhibitor (HDACi), Saha, was used. This molecule was also used in a clinical trial and was able to increase the levels of HIV-DNA in ART-treated donors [13]. Other more potent HDACis may induce stronger cytotoxic effects during HIV-1 reactivation, and cause selective cell death in CD ${ }^{+}$ $\mathrm{T}$ cells in which successful viral reactivation occurs. Different approaches are currently being tested to reactivate latently-infected cells and restore immune functions. These molecules include HDAC inhibitors, mediators of $\mathrm{T}$ cell homeostasis or antibodies to block negative regulators; they all focus on reactivating latently-infected $\mathrm{CD}^{+}{ }^{+} \mathrm{T}$ cells to render them susceptible to immune-mediated killing while also potentiating HIV-specific CTLs to kill reactivated CD4 ${ }^{+} \mathrm{T}$ cells. This review will describe the current knowledge and advances using these therapeutic strategies.

\section{CD8 T Cell-Based Vaccine Strategies for a Functional Cure}

Functional cure from HIV infection was achieved for the first time by Timothy Brown, the Berlin patient, who was given hematopoietic stem cell transplant (HSC) from CCR5 delta 32 donor (mutation of the gene required for HIV entry) [14]. Brown remains HIV free without ART after 6 years. 
Recently, two subjects from Boston, USA, with Hodgkin's lymphoma and treated with ART were given a $\mathrm{CCR}^{+/+}$haemopoietic stem-cell transplant [15]. The two subjects had undetectable HIV-DNA years after transplantation. These findings suggest that ablative conditioning, immunosuppressive treatment, and post-transplant graft-versus host might be the reasons of the functional cure, more than the CCR5 deletion.

The components of an efficient immune response able to control HIV replication after treatment interruption are still to be identified. In ECs, the natural control of HIV replication has been mainly attributed to strong $\mathrm{T}$ cell responses directed to dominant epitopes restricted by HLA types associated with viral control $[4,16,17]$. However, these responses cannot be elicited by a vaccine regimen in subjects that do not carry these HLAs. Recent studies suggested that initiating ART in early HIV infection could lead to control of HIV replication control in 5\% to $15 \%$ of individuals after analytical treatment interruption (ATI) in individuals missing the known genetic characteristics of ECs [18-27]. In the VISCONTI cohort, 14 subjects achieved long-term post-treatment control of HIV replication after ART cessation [18,21]. Very early treatment (30 h after birth) was given to the Mississippi baby that was the first case of functional cure of an infant [19]. What cured the baby is still not fully understood but one reason might be prevention of the formation of latent reservoirs by very early treatment. These rare cases initiated ART during the early/acute phase of infection and interrupted ART after some years of ART, suggesting that early treatment initiation in acute HIV infection would lead to specific immune functions that are able to control HIV replication after ART cessation. Early and prolonged ART has been recently shown to be associated with an HIV-specific CD8 ${ }^{+} \mathrm{T}$ cell cytokine profile comparable to that of long-term non-progressors [28,29]. However, the mechanisms of viral control in this small number of subjects have not been elucidated yet. Furthermore, the magnitude of $\mathrm{HIV}$-specific $\mathrm{CD}^{+} \mathrm{T}$ cells is low in these very early treated donors, which may limit studies. Moreover, no evidence of HIV-specific $\mathrm{CD}^{+} \mathrm{T}$ cells-mediated control of viral control after ART cessation was demonstrated in the VISCONTI cohort [21]. Other studies are currently testing whether the very early treatment in acute infection could lead to control of viral rebound after ATI [30,31]. The analysis of the characteristics of the immune response directed against HIV before and after ART interruption in these rare cases will provide clues that will guide the development of new vaccine interventions.

Several studies suggest the need for efficient HIV-specific $\mathrm{CD}^{+} \mathrm{T}$ cells to control viral replication after treatment cessation. HIV-specific $\mathrm{CD}^{+} \mathrm{T}$ cells are a promising tool to eliminate reactivated, latently-infected $\mathrm{CD}^{+}{ }^{\mathrm{T}} \mathrm{T}$ cells and cure HIV infection as they are already important for the control of HIV-1 replication in non-treated individuals $[16,32]$. However, upon initiation of ART, their frequency declines rapidly and few memory cells are maintained. Previous efforts aimed at augmenting HIV-specific $\mathrm{CD}^{+} \mathrm{T}$ cell responses with structured treatment interruptions or vaccine regimens in ART-treated donors and in non-human primates have not been successful to control viral replication after ART cessation. Recently, Hansen et al. described a new RhesusCMV viral vector that induced the viral control of half of the infected macaques after challenge [33]. The wide breadth and non-conventional $\mathrm{CD}^{+} \mathrm{T}$ cell responses induced by the vaccine could contribute to the dramatic control of SIV replication in the vaccinated animals [33]. These results suggest that different and more efficient $\mathrm{CD}^{+} \mathrm{T}$ cell responses targeting HIV epitopes could control HIV replication. 
HIV-specific $\mathrm{CD}^{+} \mathrm{T}$ cells play a crucial role in mediating antiviral immunity by killing the productively infected $\mathrm{CD} 4^{+} \mathrm{T}$ cells. The critical role of $\mathrm{CD} 8^{+} \mathrm{T}$ cells in controlling viral replication has been demonstrated in acute infection in the SIV model, where $\mathrm{CD} 8^{+} \mathrm{T}$ cells depletion leads to a sharp increase in viremia [34]. Several other observations suggest that HIV-specific $\mathrm{CD}^{+} \mathrm{T}$ cells are important for the control of HIV-1 replication, including the generation and maintenance of viral escape mutations in CTL epitopes or the superior control of viral replication by certain HIV-specific clonotypes restricted by HLA-B57 and B27 [16]. Yang et al. demonstrated a significant association between $\mathrm{CD}^{+} \mathrm{T}$ cell viral inhibition activity in vitro and the rate of $\mathrm{CD}^{+} \mathrm{T}$ cell loss in early HIV infection and $\mathrm{CD}^{+} \mathrm{T}$ cell decline in chronically infected individuals [35]. In a macaque model for HLA-B27 mediated viral control, the control of viral replication was associated with high frequencies of SIV-specific CD8 ${ }^{+} \mathrm{T}$ cell responses directed against three epitopes [36]. These data highlight the important role of eliciting efficient $\mathrm{CD}^{+} \mathrm{T}$ cells for the control of viral replication [23]. Previous reports have shown that in vivo induction of high-avidity, high-frequency $\mathrm{CD} 8^{+} \mathrm{T}$ cell responses were associated with antiviral protective immunity [36-38]. The selection and maintenance of high affinity clonotypes early in acute infection could play an important role in the efficient killing of infected $\mathrm{CD}^{+} \mathrm{T}$ cells after treatment interruption $[16,39,40]$. However, clonal depletion has been observed during primary HIV infection [41]. We have previously shown a marked degree of clonotypic turnover within HIV-specific $\mathrm{CD} 8^{+} \mathrm{T}$ cell populations as a consequence of antigen decay after the initiation of ART with particular clonotypes selected for their higher functional sensitivity [42]. Therefore, maturation of the TCR repertoire towards these high affinity clonotypes could play an important role in viral control after ATI. However, previous efforts aimed at augmenting $\mathrm{CD}^{+} \mathrm{T}$ cell responses in ART-treated donors with structured treatment interruption or using vaccine regimens have not been as successful as hoped to control viral replication after ART cessation [24,43-46]. Novel CD8 T cell-based vaccine strategies are therefore needed to increase the number and function of HIV-specific $\mathrm{CD}^{+} \mathrm{T}$ cells that could control viral rebound after ART cessation, with the ultimate goal of achieving spontaneous control of viral replication without treatment [47].

\section{3. "Shock and Kill" Strategy}

Several molecules currently tested in clinical trials to reactivate HIV from latently-infected $\mathrm{CD}^{+}{ }^{\mathrm{T}}$ cells have demonstrated promising in vitro and ex vivo activities in reactivating latent HIV reservoir (shock) [48-51]. These molecules include HDAC inhibitors, mediators of $\mathrm{T}$ cell homeostasis or antibodies to block negative regulators. These molecules could also differentially influence the selection, expansion, persistence and function of $\mathrm{HIV}$-specific $\mathrm{CD}^{+} \mathrm{T}$ cell responses stimulated contemporaneously by a vaccine strategy (kill).

\subsection{HDAC Inhibitors}

Post-translational modification including phosphorylation, acetylation, methylation and ubiquitination are thought to contribute to transcriptional regulation by inducing an "open" (transcriptionally permissive) vs. "closed" (transcriptionally repressive) state of chromatin. During HIV infection, many transcription factors bind to the LTR and induce silencing of the HIV promoter by recruiting histone deacetylases (HDACs). C-promoter binding factor-1 (CBF-1) and the NF-kappaB homodimer p50/p50 
are two of the transcription factors that have been shown to bind the LTR enhancer sequence thus promoting transcriptional silencing during the establishment of HIV-1 latency [52,53]. Thus, one of the promising candidate families of molecules tested in clinical trials to reactivate latent HIV reservoirs are histone deacetylase inhibitors (HDACis). Among the HDACis, valproic acid (VPA) and suberoylanilide hydroxamic acid (SAHA) have been tested in HIV infected subjects under ART. However in the first clinical trial, VPA failed to reactivate the virus from latently infected cells and thus to decrease the reservoir. Most promising results in a recent clinical trial showed that SAHA was able to reactivate viral reservoirs in subjects on ART [13]. There is limited knowledge of the chromatin remodeling and non-epigenetic effects of HDACis on the differentiation of $\mathrm{CD}^{+} \mathrm{T}$ cells in humans. Studies in mice have shown that $\mathrm{CD}^{+}{ }^{+}$cells activated without $\mathrm{CD} 4^{+}$help, fail to develop functional, protective memory and remain hypo-acetylated. Treatment with an HDACis increased histone acetylation in unaided $\mathrm{CD}^{+} \mathrm{T}$ cells and restored their ability to differentiate into functional memory cells capable of immediate cytokine production and providing protective immunity [54]. Besides being able to reactivate viral production in latently-infected $\mathrm{CD}^{+} \mathrm{T}$ cells and increase HIV antigen presentation by MHC I, HDACis could also change the fate of HIV-specific $\mathrm{CD} 8^{+} \mathrm{T}$ cells induced by a vaccine.

\subsection{Targeting Negative Regulators}

The combination of systems biology, phenotypic and functional profiles suggests that PD-1 is a good target for therapeutic interventions aimed at restoring $\mathrm{CD}^{+} \mathrm{T}$ cell function in $\mathrm{HIV}$ infection. Different groups have already shown that a PD-1 blockade in various diseases such as HIV, hepatitis $\mathrm{B}$, and hepatitis $\mathrm{C}$ is able to restore $\mathrm{T}$ cell proliferation, cytokine production and thus effector function [55-61]. While it has been suggested that blocking PD-L1 has a better capacity to restore $\mathrm{T}$ cell function than targeting PD-1 itself [55,62], in both cases blocking this interaction resulted in increased HIV-specific $\mathrm{CD}^{+} \mathrm{T}$ cell proliferation [63]. Recent in vivo studies have been conducted in the rhesus macaque SIV infection model [58,64]. Velu et al. showed that PD-1 blockade resulted in increased frequencies of SIV specific $\mathrm{CD} 8^{+} \mathrm{T}$ cells, increased cytotoxic function and decreased viral load [58]. Many groups have also shown that the exhaustion of HIV specific $\mathrm{CD}^{+} \mathrm{T}$ cells from chronic HIV infected subjects is associated with the co-expression of different negative regulators, such as PD-1, CD160 and 2B4. The most exhausted cells simultaneously express multiple negative regulatory receptors on their cell surface and their expression positively correlates with viral load and decreased cytokine production [65,66]. Blocking the interaction of CD160 and HVEM was able to enhance and rescue HIV-specific $\mathrm{CD}^{+} \mathrm{T}$ cell proliferation and cytokine production. All together, these findings are in agreement with previous studies that provide a strong rationale for initiating human clinical trials targeting PD-1 with blocking antibodies in HIV-infected subjects. Blocking PD-1 or multiple negative regulators might not only increase effector functions of exhausted HIV-specific $\mathrm{CD}^{+} \mathrm{T}$ cells but could also reactivate the viral reservoir from latently infected $\mathrm{CD}^{+} \mathrm{T}$ cells [67]. Thus, combination therapy that combines vaccination under ART with blocking antibodies for PD-1 signaling might prove to be more potent in increasing $\mathrm{CD}^{+} \mathrm{T}$ cell killing of latently infected cells and to preventing reactivated virus from re-infecting new $\mathrm{CD} 4^{+} \mathrm{T}$ cells. 


\subsection{Gamma Chain Cytokines}

Gamma chain cytokines (IL-2, IL-15, IL-7 and IL-21) that converge on the STAT5A/B signaling pathway have been considered as candidates to regulate reservoir reactivation. These cytokines can also be used as modulators of a vaccine immune therapy [68]. During HIV infection, production of some of these cytokines, such as IL-2 and IL-15, is downregulated, while IL-7 levels are increased as a consequence of lymphopenia. Extensive phase I and II studies were done in the late 1990s with IL-2 as a candidate cytokine for treatment of subjects with HIV infection. These studies demonstrated that this cytokine increases the frequency of naïve and central memory $\left(\mathrm{T}_{\mathrm{CM}}\right) \mathrm{CD} 4^{+} \mathrm{T}$ cells, as well as $\mathrm{CD} 8^{+}$ cytotoxic functions [69-71]. However, phase III clinical trials demonstrated that IL-2 increased CD25 and FOXOp3 expression (and thus regulatory $\mathrm{T}$ cells), which was associated with increased risk of opportunistic diseases [71-73]. Similar to IL-2, IL-15 signals through the IL-2RB (CD122) and $\gamma$-chain (CD132) receptors and plays an essential role in T cell survival [74]. Although both IL-2 and IL-15 induce identical signal-transduction pathways and proliferative responses in T cells and NK cells, IL-2 favors maintenance of peripheral regulatory $\mathrm{T}$ cells and participates in activation-induced cell death while IL-15 preferentially stimulates expansion of $\mathrm{CD}^{+} \mathrm{T}$ cells, NK, and NKT cells [75]. Stimulation of cells from HIV-infected subjects with IL-15, enhances the frequency of effector memory CD $8^{+}$ $\mathrm{T}$ cell, promotes their survival and cytotoxic functions [76-80]. Stimulation with IL-15 might also relieve HIV-specific $\mathrm{CD}^{+} \mathrm{T}$ cells from their functional and phenotypic block in a transitional memory $\left(\mathrm{T}_{\mathrm{TM}}\right)$ phenotype $\left(\mathrm{CCR} 7^{-}, \mathrm{CD} 7^{+}, \mathrm{CD} 4 \mathrm{RA}^{-}\right)$and induce their differentiation in functional effector antigen-specific $\mathrm{CD}^{+} \mathrm{T}$ cells [67]. Preclinical studies have shown that IL-15 enhances CTL responses in murine tumor models and the administration of IL-15 in combination with anti-PD-L1and anti-CTLA-4 antibodies showed greater cytolytic and effector functions on the $\mathrm{CD}^{+} \mathrm{T}$ cells of metastatic tumor-bearing animals [81-85]. Studies in non-human primates showed that daily administration of IL-15 was not only safe but increased the frequency of effector memory $\left(\mathrm{T}_{\mathrm{EM}}\right) \mathrm{CD} 8^{+}$ $\mathrm{T}$ cells of 100 -fold $[86,87]$. However another study showed that administration of IL-15 in chronically SIV infected macaques, in combination with ART, resulted in a delay in viral suppression and failed in the reconstitution of $\mathrm{CD}^{+} \mathrm{T}$ cell numbers after ART interruptions [88].

IL-7 regulates T-cell maturation and supports peripheral T cell homeostasis. Preclinical studies in SIV-infected macaques showed that IL-7 injection was not toxic and was not increasing viremia [89,90]. Phase I/II trials in HIV infected subjects with persistent lymphopenia have demonstrated that the administration of IL-7 was able to restore circulating CD4 T-cell counts as well as the frequency of $\mathrm{CD}^{+} \mathrm{T}$ cells, mainly those with a central memory $\left(\mathrm{T}_{\mathrm{CM}}\right)$ phenotype [91] without any effect on the number of regulatory T cells. IL-2 1 is another $\gamma$-chain cytokine that induces a potent cytotoxic activity of $\mathrm{NK}$ and $\mathrm{CD} 8^{+} \mathrm{T}$ cells from HIV infected subjects and promotes antiviral activity in human $\mathrm{CD}^{+} \mathrm{T}$ cells [92]. HIV-specific IL- $21^{+} \mathrm{CD} 4^{+} \mathrm{T}$ cell responses contribute to durable viral control through the modulation of HIV-specific $\mathrm{CD}^{+} \mathrm{T}$ cell function [93]. The benefic role of this cytokine has been confirmed in a pilot study where IL-21 was injected in SIV infected rhesus macaques in late-stage disease [94]. Administration of IL-21 resulted in increased cytotoxic effector molecules in $\mathrm{CD}^{+} \mathrm{T}$ cells and NK cells and as well as enhanced B cell differentiation.

Eradication strategies should rely not only in boosting CTL activity, but also at enhancing HIV reactivation from latently infected $\mathrm{CD}^{+} \mathrm{T}$ cells. Few studies have shown that among the $\gamma$-chain 
cytokines, IL-7 is a potent and proviral strain-specific inducer of latent HIV-1 cellular reservoirs [50,95]. Vandergeten et al. showed that IL-7 increases reactivation in productively infected cells but has no effect in latently infected $\mathrm{CD}^{+} \mathrm{T}$ cells whereas IL-15 seems to be a more potent inducer of viral production from latently infected CD4 ${ }^{+} \mathrm{T}$ cells than IL-7 [96,97]. Administration of IL-15 during the contraction phase (7-14 days) and not during the expansion phase could have a better effect in the enhancement of HIV-specific $\mathrm{CD}^{+} \mathrm{T}$ cells response after vaccination. Further studies should be done to determine the timing of cytokine delivery in combination with a vaccine regimen. All together these findings provide a good rationale for complementing vaccine therapy with $\gamma$-chain cytokines in eradication strategies aimed at purging latent HIV from $\mathrm{CD} 4^{+} \mathrm{T}$ cells and at boosting HIV-specific $\mathrm{CD}^{+} \mathrm{T}$ cell responses.

\section{New Assays to Monitor an Effective Combined Therapy for a Functional Cure}

Few parameters including frequency, phenotype, and cytokine production are commonly used to assess $\mathrm{T}$ cell responses [98]. The frequency and phenotype of $\mathrm{T}$ cells are limited in evaluating their functions. T cell poly-functionality has been suggested to correlate with HIV disease control, however it is still unclear if this feature is sufficient to provide $\mathrm{T}$ cell-mediated immune control [99,100]. Therefore, new functional assays have to be developed to measure $\mathrm{T}$ cell functions focusing on select immune parameters known to impact the control of HIV replication. The cytolytic function of $\mathrm{CD}^{+} \mathrm{T}$ cells is critical for eradicating HIV-infected $\mathrm{CD}^{+} \mathrm{T}$ cells and control viral replication after ART interruption. New in vitro methods to evaluate the viral replication inhibition by $\mathrm{CD}^{+} \mathrm{T}$ cells have been recently developed $[12,101,102]$ and can be used to recapitulate the in vivo cytotoxic activity of $\mathrm{CD}^{+} \mathrm{T}$ cells after ATI. A study by Yang et al. demonstrated a significant association between $\mathrm{CD} 8^{+} \mathrm{T}$ cell antiviral activity in vitro and the rate of loss in early HIV-1 infection and $\mathrm{CD}^{+} \mathrm{T}$ cell decline in chronically infected individuals using an in vitro viral inhibition assay [35]. We developed a new assay to quantify the intrinsic killing capacity of HIV-specific $\mathrm{CD}^{+} \mathrm{T}$ cells measured in lytic units [103]. Using this assay, we have observed that HIV-specific $\mathrm{CD} 8^{+} \mathrm{T}$ cells in primary infection exhibited a significantly higher cytotoxic capacity than HIV-specific $\mathrm{CD} 8^{+} \mathrm{T}$ cells in chronic infection [104]. These new functional cell-based assays can help determining if an enhanced cytotoxic activity of CD $8^{+}$ $\mathrm{T}$ cells is associated with viral control after ATI. Furthermore, new assays that can recapitulate the killing of primary latently-infected $\mathrm{CD}^{+} \mathrm{T}$ cells by HIV-specific CTLs from ART treated donors would be an important platform to test the immune intervention strategies of reservoir eradication as it would provide the direct readout of elimination of reactivated latently-infected cells.

\section{Conclusions}

New $\mathrm{CD}^{+}$T cell-based vaccination strategies under ART should be evaluated in combination with reactivating agents to achieve control of viral replication upon ART interruption. Immunotherapeutic interventions not only need to increase the number of HIV-specific $\mathrm{CD} 8^{+} \mathrm{T}$ cells in vivo but also induce efficient cytotoxic $\mathrm{CD} 8^{+} \mathrm{T}$ cells to kill reactivated latently-infected CD4 $\mathrm{T}$ cells. However, the mechanisms that underlie such successful immunotherapies remain unknown. These immune interventions have to be combined with contemporaneous strategies aimed at reactivation of the latent HIV reservoir. Combinations could also include new strategies such as vaccination with a biologically 
active Tat protein that protected non-human primates against an R5-SHIV challenge by neutralizing antibodies [105]. These combinations have to be judiciously selected to potentiate the vaccine-induced response. The effect of reactivating agents on the immune response induced by therapeutic interventions has to be also evaluated. The accurate assessment of new therapeutic vaccine regimen would accelerate the development of successful therapies for a functional cure.

\section{Acknowledgments}

This work was supported by the Office of Tourism, Trade and Economic Development of Florida.

\section{Conflicts of Interest}

The authors declare no conflicts of interest.

\section{References}

1. Corbeau, P.; Reynes, J. Immune reconstitution under antiretroviral therapy: The new challenge in HIV-1 infection. Blood 2011, 117, 5582-5590.

2. Hunt, P.W. HIV and inflammation: Mechanisms and consequences. Curr. HIV/AIDS Rep. 2012, 9, 139-147.

3. Vanham, G.; van Gulck, E. Can immunotherapy be useful as a "functional cure" for infection with Human Immunodeficiency Virus-1? Retrovirology 2012, 9, doi:10.1186/1742-4690-9-72.

4. Carrington, M.; Walker, B.D. Immunogenetics of spontaneous control of HIV. Annu. Rev. Med. 2012, 63, 131-145.

5. Mcmichael, A.J.; Borrow, P.; Tomaras, G.D.; Goonetilleke, N.; Haynes, B.F. The immune response during acute HIV-1 infection: Clues for vaccine development. Nat. Rev. Immunol. 2009, 10, 11-23.

6. Chun, T.W.; Finzi, D.; Margolick, J.; Chadwick, K.; Schwartz, D.; Siliciano, R.F. In vivo fate of HIV-1-infected T cells: Quantitative analysis of the transition to stable latency. Nat. Med. 1995, $1,1284-1290$.

7. Finzi, D.; Hermankova, M.; Pierson, T.; Carruth, L.M.; Buck, C.; Chaisson, R.E.; Quinn, T.C.; Chadwick, K.; Margolick, J.; Brookmeyer, R.; et al. Identification of a reservoir for HIV-1 in patients on highly active antiretroviral therapy. Science 1997, 278, 1295-1300.

8. Wong, J.K.; Hezareh, M.; Gunthard, H.F.; Havlir, D.V.; Ignacio, C.C.; Spina, C.A.; Richman, D.D. Recovery of replication-competent HIV despite prolonged suppression of plasma viremia. Science 1997, 278, 1291-1295.

9. Chun, T.W.; Engel, D.; Berrey, M.M.; Shea, T.; Corey, L.; Fauci, A.S. Early establishment of a pool of latently infected, resting $\mathrm{CD}^{+} \mathrm{T}$ cells during primary HIV-1 infection. Proc. Natl. Acad. Sci. USA 1998, 95, 8869-8873.

10. Finzi, D.; Blankson, J.; Siliciano, J.D.; Margolick, J.B.; Chadwick, K.; Pierson, T.; Smith, K.; Lisziewicz, J.; Lori, F.; Flexner, C.; et al. Latent infection of $\mathrm{CD}^{+} \mathrm{T}$ cells provides a mechanism for lifelong persistence of HIV-1, even in patients on effective combination therapy. Nat. Med. 1999, 5, 512-517. 
11. Deeks, S.G.; Autran, B.; Berkhout, B.; Benkirane, M.; Cairns, S.; Chomont, N.; Chun, T.W.; Churchill, M.; di Mascio, M.; Katlama, C.; et al. Towards an HIV cure: A global scientific strategy. Nat. Rev. Immunol. 2012, 12, 607-614.

12. Shan, L.; Deng, K.; Shroff, N.S.; Durand, C.M.; Rabi, S.A.; Yang, H.C.; Zhang, H.; Margolick, J.B.; Blankson, J.N.; Siliciano, R.F. Stimulation of HIV-1-specific cytolytic T lymphocytes facilitates elimination of latent viral reservoir after virus reactivation. Immunity 2012, 36, 491-501.

13. Archin, N.M.; Liberty, A.L.; Kashuba, A.D.; Choudhary, S.K.; Kuruc, J.D.; Crooks, A.M.; Parker, D.C.; Anderson, E.M.; Kearney, M.F.; Strain, M.C.; et al. Administration of vorinostat disrupts HIV-1 latency in patients on antiretroviral therapy. Nature 2012, 487, 482-485.

14. Hutter, G.; Nowak, D.; Mossner, M.; Ganepola, S.; Mussig, A.; Allers, K.; Schneider, T.; Hofmann, J.; Kucherer, C.; Blau, O.; et al. Long-term control of HIV by CCR5 Delta32/Delta32 stem-cell transplantation. N. Engl. J. Med. 2009, 360, 692-698.

15. Henrich, T.J.; Hu, Z.; Li, J.Z.; Sciaranghella, G.; Busch, M.P.; Keating, S.M.; Gallien, S.; Lin, N.H.; Giguel, F.F.; Lavoie, L.; et al. Long-term reduction in peripheral blood HIV type 1 reservoirs following reduced-intensity conditioning allogeneic stem cell transplantation. J. Infect. Dis. 2013, 207, 1694-1702.

16. Chen, H.; Ndhlovu, Z.M.; Liu, D.; Porter, L.C.; Fang, J.W.; Darko, S.; Brockman, M.A.; Miura, T.; Brumme, Z.L.; Schneidewind, A.; et al. TCR clonotypes modulate the protective effect of HLA class I molecules in HIV-1 infection. Nat. Immunol. 2012, 13, 691-700.

17. Walker, B.D.; Yu, X.G. Unravelling the mechanisms of durable control of HIV-1. Nat. Rev. Immunol. 2013, 13, 487-498.

18. Hocqueloux, L.; Prazuck, T.; Avettand-Fenoel, V.; Lafeuillade, A.; Cardon, B.; Viard, J.P.; Rouzioux, C. Long-term immunovirologic control following antiretroviral therapy interruption in patients treated at the time of primary HIV-1 infection. AIDS 2010, 24, 1598-1601.

19. Persaud, D.; Gay, H.; Ziemniak, C.; Chen, Y.; Piatak, M.; Chun, T.-W.; Strain, M.; Richman, D.; Luzuriaga, K. Functional HIV cure after very early ART of an infected infant. Available online: http://www.retroconference.org/2013b/Abstracts/47897.htm (accessed on 1 September 2013).

20. Cohen, J. Early treatment may have cured infant of HIV infection. Science 2013, 339, doi:10.1126/science.339.6124.1134.

21. Saez-Cirion, A.; Bacchus, C.; Hocqueloux, L.; Avettand-Fenoel, V.; Girault, I.; Lecuroux, C.; Potard, V.; Versmisse, P.; Melard, A.; Prazuck, T.; et al. Post-treatment HIV-1 controllers with a long-term virological remission after the interruption of early initiated antiretroviral therapy ANRS VISCONTI Study. PLoS Pathog. 2013, 9, e1003211.

22. Strain, M.C.; Little, S.J.; Daar, E.S.; Havlir, D.V.; Gunthard, H.F.; Lam, R.Y.; Daly, O.A.; Nguyen, J.; Ignacio, C.C.; Spina, C.A.; et al. Effect of treatment, during primary infection, on establishment and clearance of cellular reservoirs of HIV-1. J. Infect. Dis. 2005, 191, 1410-1418.

23. Freel, S.A.; Picking, R.A.; Ferrari, G.; Ding, H.; Ochsenbauer, C.; Kappes, J.C.; Kirchherr, J.L.; Soderberg, K.A.; Weinhold, K.J.; Cunningham, C.K.; et al. Initial HIV-1 antigen-specific CD8 ${ }^{+}$ T cells in acute HIV-1 infection inhibit transmitted/founder virus replication. J. Virol. 2012, 86, 6835-6846. 
24. Bolton, D.L.; Minang, J.T.; Trivett, M.T.; Song, K.; Tuscher, J.J.; Li, Y.; Piatak, M., Jr.; O'Connor, D.; Lifson, J.D.; Roederer, M.; et al. Trafficking, persistence, and activation state of adoptively transferred allogeneic and autologous Simian Immunodeficiency Virus-specific $\mathrm{CD} 8^{+} \mathrm{T}$ cell clones during acute and chronic infection of rhesus macaques. J. Immunol. 2010, 184, 303-314.

25. Trkola, A.; Kuster, H.; Rusert, P.; Joos, B.; Fischer, M.; Leemann, C.; Manrique, A.; Huber, M.; Rehr, M.; Oxenius, A.; et al. Delay of HIV-1 rebound after cessation of antiretroviral therapy through passive transfer of human neutralizing antibodies. Nat. Med. 2005, 11, 615-622.

26. Tomaras, G.D.; Haynes, B.F. HIV-1-specific antibody responses during acute and chronic HIV-1 infection. Curr. Opin. HIV AIDS 2009, 4, 373-379.

27. Xiao, P.; Zhao, J.; Patterson, L.J.; Brocca-Cofano, E.; Venzon, D.; Kozlowski, P.A.; Hidajat, R.; Demberg, T.; Robert-Guroff, M. Multiple vaccine-elicited nonneutralizing antienvelope antibody activities contribute to protective efficacy by reducing both acute and chronic viremia following simian/human immunodeficiency virus SHIV89.6P challenge in rhesus macaques. J. Virol. 2010, 84, 7161-7173.

28. Altfeld, M.; Rosenberg, E.S.; Shankarappa, R.; Mukherjee, J.S.; Hecht, F.M.; Eldridge, R.L.; Addo, M.M.; Poon, S.H.; Phillips, M.N.; Robbins, G.K.; et al. Cellular immune responses and viral diversity in individuals treated during acute and early HIV-1 infection. J. Exp. Med. 2001, 193, 169-180.

29. Cellerai, C.; Harari, A.; Stauss, H.; Yerly, S.; Geretti, A.-M.; Carroll, A.; Yee, T.; Ainsworth, J.; Williams, I.; Sweeney, J.; et al. Early and prolonged antiretroviral therapy is associated with an HIV-1-specific T-cell profile comparable to that of long-term non-progressors. PLoS One 2011, 6, e18164.

30. Ananworanich, J.; Schuetz, A.; Vandergeeten, C.; Sereti, I.; de Souza, M.; Rerknimitr, R.; Dewar, R.; Marovich, M.; van Griensven, F.; Sekaly, R.; et al. Impact of multi-targeted antiretroviral treatment on gut $\mathrm{T}$ cell depletion and HIV reservoir seeding during acute HIV infection. PLoS One 2012, 7, e33948.

31. Jain, V.; Hartogensis, W.; Bacchetti, P.; Hunt, P.W.; Hatano, H.; Sinclair, E.; Epling, L.; Lee, T.H.; Busch, M.P.; McCune, J.M.; et al. Antiretroviral Therapy initiated within 6 months of HIV infection is associated with lower T-cell activation and smaller HIV reservoir size. J. Infect. Dis. 2013, 208, 1201-1211.

32. Iglesias, M.C.; Almeida, J.R.; Fastenackels, S.; van Bockel, D.J.; Hashimoto, M.; Venturi, V.; Gostick, E.; Urrutia, A.; Wooldridge, L.; Clement, M.; et al. Escape from highly effective public CD8 ${ }^{+}$T-cell clonotypes by HIV. Blood 2011, 118, 2138-2149.

33. Hansen, S.G.; Sacha, J.B.; Hughes, C.M.; Ford, J.C.; Burwitz, B.J.; Scholz, I.; Gilbride, R.M.; Lewis, M.S.; Gilliam, A.N.; Ventura, A.B.; et al. Cytomegalovirus vectors violate $\mathrm{CD}^{+} \mathrm{T}$ cell epitope recognition paradigms. Science 2013, 340, doi:10.1126/science.1237874.

34. Schmitz, J.E.; Kuroda, M.J.; Santra, S.; Sasseville, V.G.; Simon, M.A.; Lifton, M.A.; Racz, P.; Tenner-Racz, K.; Dalesandro, M.; Scallon, B.J.; et al. Control of viremia in simian immunodeficiency virus infection by $\mathrm{CD}^{+}$lymphocytes. Science 1999, 283, 857-860.

35. Yang, H.; Wu, H.; Hancock, G.; Clutton, G.; Sande, N.; Xu, X.; Yan, H.; Huang, X.; Angus, B.; Kuldanek, K.; et al. Antiviral Inhibitory Capacity of $\mathrm{CD}^{+} \mathrm{T}$ cells predicts the rate of $\mathrm{CD} 4^{+}$ T-cell decline in HIV-1 infection. J. Infect. Dis. 2012, 206, 552-561. 
36. Mudd, P.A.; Martins, M.A.; Ericsen, A.J.; Tully, D.C.; Power, K.A.; Bean, A.T.; Piaskowski, S.M.; Duan, L.; Seese, A.; Gladden, A.D.; et al. Vaccine-induced $\mathrm{CD}^{+} \mathrm{T}$ cells control AIDS virus replication. Nature 2012, 491, 129-133.

37. Sedlik, C.; Dadaglio, G.; Saron, M.F.; Deriaud, E.; Rojas, M.; Casal, S.I.; Leclerc, C. In vivo induction of a high-avidity, high-frequency cytotoxic T-lymphocyte response is associated with antiviral protective immunity. J. Virol. 2000, 74, 5769-5775.

38. Ladell, K.; Hashimoto, M.; Iglesias, M.C.; Wilmann, P.G.; McLaren, J.E.; Gras, S.; Chikata, T.; Kuse, N.; Fastenackels, S.; Gostick, E.; et al. A Molecular basis for the control of preimmune escape variants by HIV-specific $\mathrm{CD}^{+}$T cells. Immunity 2013, 38, 425-436.

39. Almeida, J.R.; Price, D.A.; Papagno, L.; Arkoub, Z.A.; Sauce, D.; Bornstein, E.; Asher, T.E.; Samri, A.; Schnuriger, A.; Theodorou, I.; et al. Superior control of HIV-1 replication by CD8 ${ }^{+} \mathrm{T}$ cells is reflected by their avidity, polyfunctionality, and clonal turnover. J. Exp. Med. 2007, 204, 2473-2485.

40. Almeida, J.R.; Sauce, D.; Price, D.A.; Papagno, L.; Shin, S.Y.; Moris, A.; Larsen, M.; Pancino, G.; Douek, D.C.; Autran, B.; et al. Antigen sensitivity is a major determinant of $\mathrm{CD}^{+} \mathrm{T}$-cell polyfunctionality and HIV-suppressive activity. Blood 2009, 113, 6351-6360.

41. Lichterfeld, M.; Yu, X.G.; Mui, S.K.; Williams, K.L.; Trocha, A.; Brockman, M.A.; Allgaier, R.L.; Waring, M.T.; Koibuchi, T.; Johnston, M.N.; et al. Selective depletion of high-avidity human immunodeficiency virus type $1(\mathrm{HIV}-1)$-specific $\mathrm{CD}^{+} \mathrm{T}$ cells after early HIV-1 infection. J. Virol. 2007, 81, 4199-4214.

42. Janbazian, L.; Price, D.A.; Canderan, G.; Filali-Mouhim, A.; Asher, T.E.; Ambrozak, D.R.; Scheinberg, P.; Boulassel, M.R.; Routy, J.P.; Koup, R.A.; et al. Clonotype and repertoire changes drive the functional improvement of HIV-specific CD8 $\mathrm{T}$ cell populations under conditions of limited antigenic stimulation. J. Immunol. 2012, 188, 1156-1167.

43. Rosenberg, E.S.; Altfeld, M.; Poon, S.H.; Phillips, M.N.; Wilkes, B.M.; Eldridge, R.L.; Robbins, G.K.; D’Aquila, R.T.; Goulder, P.J.; Walker, B.D. Immune control of HIV-1 after early treatment of acute infection. Nature 2000, 407, 523-526.

44. Lifson, J.D.; Rossio, J.L.; Piatak, M., Jr.; Parks, T.; Li, L.; Kiser, R.; Coalter, V.; Fisher, B.; Flynn, B.M.; Czajak, S.; et al. Role of $\mathrm{CD}^{+}$lymphocytes in control of simian immunodeficiency virus infection and resistance to rechallenge after transient early antiretroviral treatment. J. Virol. 2001, 75, 10187-10199.

45. Von Wyl, V.; Gianella, S.; Fischer, M.; Niederoest, B.; Kuster, H.; Battegay, M.; Bernasconi, E.; Cavassini, M.; Rauch, A.; Hirschel, B.; et al. Early antiretroviral therapy during primary HIV-1 infection results in a transient reduction of the viral setpoint upon treatment interruption. PLoS One 2011, 6, e27463.

46. Altfeld, M.; Walker, B.D. Less is more? STI in acute and chronic HIV-1 infection. Nat. Med. 2001, 7, 881-884.

47. Chun, T.W.; Justement, J.S.; Moir, S.; Hallahan, C.W.; Ehler, L.A.; Liu, S.; Mclaughlin, M.; Dybul, M.; Mican, J.M.; Fauci, A.S. Suppression of HIV replication in the resting $\mathrm{CD}^{+}{ }^{+}$T cell reservoir by autologous $\mathrm{CD} 8^{+} \mathrm{T}$ cells: Implications for the development of therapeutic strategies. Proc. Natl. Acad. Sci. USA 2001, 98, 253-258. 
48. Kulkosky, J.; Culnan, D.M.; Roman, J.; Dornadula, G.; Schnell, M.; Boyd, M.R.; Pomerantz, R.J. Prostratin: Activation of latent HIV-1 expression suggests a potential inductive adjuvant therapy for HAART. Blood 2001, 98, 3006-3015.

49. Korin, Y.D.; Brooks, D.G.; Brown, S.; Korotzer, A.; Zack, J.A. Effects of prostratin on T-cell activation and human immunodeficiency virus latency. J. Virol. 2002, 76, 8118-8123.

50. Wang, F.X.; Xu, Y.; Sullivan, J.; Souder, E.; Argyris, E.G.; Acheampong, E.A.; Fisher, J.; Sierra, M.; Thomson, M.M.; Najera, R.; et al. IL-7 is a potent and proviral strain-specific inducer of latent HIV-1 cellular reservoirs of infected individuals on virally suppressive HAART. J. Clin. Invest. 2005, 115, 128-137.

51. Chomont, N.; El-Far, M.; Ancuta, P.; Trautmann, L.; Procopio, F.A.; Yassine-Diab, B.; Boucher, G.; Boulassel, M.R.; Ghattas, G.; Brenchley, J.M.; et al. HIV reservoir size and persistence are driven by T cell survival and homeostatic proliferation. Nat. Med. 2009, 15, 893-900.

52. Tyagi, M.; Karn, J. CBF-1 promotes transcriptional silencing during the establishment of HIV-1 latency. EMBO J. 2007, 26, 4985-4995.

53. Williams, S.A.; Chen, L.F.; Kwon, H.; Ruiz-Jarabo, C.M.; Verdin, E.; Greene, W.C. NF-kappaB p50 promotes HIV latency through HDAC recruitment and repression of transcriptional initiation. EMBO J. 2006, 25, 139-149.

54. Akimova, T.; Beier, U.H.; Liu, Y.; Wang, L.; Hancock, W.W. Histone/protein deacetylases and T-cell immune responses. Blood 2012, 119, 2443-2451.

55. Trautmann, L.; Janbazian, L.; Chomont, N.; Said, E.A.; Gimmig, S.; Bessette, B.; Boulassel, M.R.; Delwart, E.; Sepulveda, H.; Balderas, R.S.; et al. Upregulation of PD-1 expression on HIV-specific $\mathrm{CD}^{+} \mathrm{T}$ cells leads to reversible immune dysfunction. Nat. Med. 2006, 12, 1198-1202.

56. Radziewicz, H.; Ibegbu, C.C.; Fernandez, M.L.; Workowski, K.A.; Obideen, K.; Wehbi, M.; Hanson, H.L.; Steinberg, J.P.; Masopust, D.; Wherry, E.J.; et al. Liver-infiltrating lymphocytes in chronic human hepatitis $\mathrm{C}$ virus infection display an exhausted phenotype with high levels of PD-1 and low levels of CD127 expression. J. Virol. 2007, 81, 2545-2553.

57. Day, C.L.; Kaufmann, D.E.; Kiepiela, P.; Brown, J.A.; Moodley, E.S.; Reddy, S.; Mackey, E.W.; Miller, J.D.; Leslie, A.J.; DePierres, C.; et al. PD-1 expression on HIV-specific T cells is associated with T-cell exhaustion and disease progression. Nature 2006, 443, 350-354.

58. Velu, V.; Titanji, K.; Zhu, B.; Husain, S.; Pladevega, A.; Lai, L.; Vanderford, T.H.; Chennareddi, L.; Silvestri, G.; Freeman, G.J.; et al. Enhancing SIV-specific immunity in vivo by PD-1 blockade. Nature 2009, 458, 206-210.

59. Nakamoto, N.; Kaplan, D.E.; Coleclough, J.; Li, Y.; Valiga, M.E.; Kaminski, M.; Shaked, A.; Olthoff, K.; Gostick, E.; Price, D.A.; et al. Functional restoration of HCV-specific CD8 T cells by PD-1 blockade is defined by PD-1 expression and compartmentalization. Gastroenterology 2008, 134, 1927-1937.

60. Petrovas, C.; Casazza, J.P.; Brenchley, J.M.; Price, D.A.; Gostick, E.; Adams, W.C.; Precopio, M.L.; Schacker, T.; Roederer, M.; Douek, D.C.; et al. PD-1 is a regulator of virus-specific CD8 ${ }^{+}$T cell survival in HIV infection. J. Exp. Med. 2006, 203, 2281-2292.

61. Boni, C.; Fisicaro, P.; Valdatta, C.; Amadei, B.; di Vincenzo, P.; Giuberti, T.; Laccabue, D.; Zerbini, A.; Cavalli, A.; Missale, G.; et al. Characterization of hepatitis B virus (HBV)-specific T-cell dysfunction in chronic HBV infection. J. Virol. 2007, 81, 4215-4225. 
62. Forler, D.; Kocher, T.; Rode, M.; Gentzel, M.; Izaurralde, E.; Wilm, M. An efficient protein complex purification method for functional proteomics in higher eukaryotes. Nat. Biotechnol. 2003, 21, 89-92.

63. Rosignoli, G.; Lim, C.H.; Bower, M.; Gotch, F.; Imami, N. Programmed death (PD)-1 molecule and its ligand PD-L1 distribution among memory CD4 and CD8 T cell subsets in human immunodeficiency virus-1-infected individuals. Clin. Exp. Immunol. 2009, 157, 90-97.

64. Titanji, K.; Velu, V.; Chennareddi, L.; Vijay-Kumar, M.; Gewirtz, A.T.; Freeman, G.J.; Amara, R.R. Acute depletion of activated memory B cells involves the PD-1 pathway in rapidly progressing SIV-infected macaques. J. Clin. Invest. 2010, 120, 3878-3890.

65. Peretz, Y.; He, Z.; Shi, Y.; Yassine-Diab, B.; Goulet, J.P.; Bordi, R.; Filali-Mouhim, A.; Loubert, J.B.; El-Far, M.; Dupuy, F.P.; et al. CD160 and PD-1 co-expression on HIV-specific CD8 T cells defines a subset with advanced dysfunction. PLoS Pathog. 2012, 8, e1002840.

66. Yamamoto, T.; Price, D.A.; Casazza, J.P.; Ferrari, G.; Nason, M.; Chattopadhyay, P.K.; Roederer, M.; Gostick, E.; Katsikis, P.D.; Douek, D.C.; et al. Surface expression patterns of negative regulatory molecules identify determinants of virus-specific $\mathrm{CD} 8^{+} \mathrm{T}$-cell exhaustion in HIV infection. Blood 2011, 117, 4805-4815.

67. Katlama, C.; Deeks, S.G.; Autran, B.; Martinez-Picado, J.; van Lunzen, J.; Rouzioux, C.; Miller, M.; Vella, S.; Schmitz, J.E.; Ahlers, J.; et al. Barriers to a cure for HIV: New ways to target and eradicate HIV-1 reservoirs. Lancet 2013, 381, 2109-2117.

68. Schluns, K.S.; Lefrancois, L. Cytokine control of memory T-cell development and survival. Nat. Rev. Immunol. 2003, 3, 269-279.

69. Kovacs, J.A.; Vogel, S.; Albert, J.M.; Falloon, J.; Davey, R.T., Jr.; Walker, R.E.; Polis, M.A.; Spooner, K.; Metcalf, J.A.; Baseler, M.; et al. Controlled trial of interleukin-2 infusions in patients infected with the human immunodeficiency virus. N. Engl. J. Med. 1996, 335, 1350-1356.

70. Kovacs, J.A.; Baseler, M.; Dewar, R.J.; Vogel, S.; Davey, R.T., Jr.; Falloon, J.; Polis, M.A.; Walker, R.E.; Stevens, R.; Salzman, N.P.; et al. Increases in CD4 T lymphocytes with intermittent courses of interleukin-2 in patients with human immunodeficiency virus infection. A preliminary study. N. Engl. J. Med. 1995, 332, 567-575.

71. Sereti, I.; Imamichi, H.; Natarajan, V.; Imamichi, T.; Ramchandani, M.S.; Badralmaa, Y.; Berg, S.C.; Metcalf, J.A.; Hahn, B.K.; Shen, J.M.; et al. In vivo expansion of CD4CD45RO ${ }^{-}$CD25 T cells expressing foxP3 in IL-2-treated HIV-infected patients. J. Clin. Invest. 2005, 115, 1839-1847.

72. Weiss, L.; Letimier, F.A.; Carriere, M.; Maiella, S.; Donkova-Petrini, V.; Targat, B.; Benecke, A.; Rogge, L.; Levy, Y. In vivo expansion of naive and activated $\mathrm{CD} 4{ }^{+} \mathrm{CD} 25^{+} \mathrm{FOXP}^{+}$regulatory $\mathrm{T}$ cell populations in interleukin-2-treated HIV patients. Proc. Natl. Acad. Sci. USA 2010, 107, 10632-10637.

73. Abrams, D.; Levy, Y.; Losso, M.H.; Babiker, A.; Collins, G.; Cooper, D.A.; Darbyshire, J.; Emery, S.; Fox, L.; Gordin, F.; et al. Interleukin-2 therapy in patients with HIV infection. N. Engl. J. Med. 2009, 361, 1548-1559.

74. Wu, Z.; Xue, H.H.; Bernard, J.; Zeng, R.; Issakov, D.; Bollenbacher-Reilley, J.; Belyakov, I.M.; Oh, S.; Berzofsky, J.A.; Leonard, W.J. The IL-15 receptor \{alpha\} chain cytoplasmic domain is critical for normal IL-15Ralpha function but is not required for trans-presentation. Blood 2008, 112, 4411-4419. 
75. Ring, A.M.; Lin, J.-X.; Feng, D.; Mitra, S.; Rickert, M.; Bowman, G.R.; Pande, V.S.; Li, P.; Moraga, I.; Spolski, R.; et al. Mechanistic and structural insight into the functional dichotomy between IL-2 and IL-15. Nat. Immunol. 2012, 13, 1187-1195.

76. Marks-Konczalik, J.; Dubois, S.; Losi, J.M.; Sabzevari, H.; Yamada, N.; Feigenbaum, L.; Waldmann, T.A.; Tagaya, Y. IL-2-induced activation-induced cell death is inhibited in IL-15 transgenic mice. Proc. Natl. Acad. Sci. USA 2000, 97, 11445-11450.

77. Waldmann, T.A.; Tagaya, Y. The multifaceted regulation of interleukin-15 expression and the role of this cytokine in NK cell differentiation and host response to intracellular pathogens. Annu. Rev. Immunol. 1999, 17, 19-49.

78. Mueller, Y.M.; Petrovas, C.; Bojczuk, P.M.; Dimitriou, I.D.; Beer, B.; Silvera, P.; Villinger, F.; Cairns, J.S.; Gracely, E.J.; Lewis, M.G.; et al. Interleukin-15 increases effector memory CD8 ${ }^{+} \mathrm{T}$ cells and NK cells in simian immunodeficiency virus-infected macaques. J. Virol. 2005, 79, 4877-4885.

79. Mueller, Y.M.; Bojczuk, P.M.; Halstead, E.S.; Kim, A.H.; Witek, J.; Altman, J.D.; Katsikis, P.D. IL-15 enhances survival and function of HIV-specific CD8 ${ }^{+}$T cells. Blood 2003, 101, 1024-1029.

80. Rodriguez, A.R.; Arulanandam, B.P.; Hodara, V.L.; McClure, H.M.; Cobb, E.K.; Salas, M.T.; White, R.; Murthy, K.K. Influence of interleukin-15 on $\mathrm{CD}^{+}$natural killer cells in human immunodeficiency virus type 1-infected chimpanzees. J. Gen. Virol. 2007, 88, 641-651.

81. Klebanoff, C.A.; Finkelstein, S.E.; Surman, D.R.; Lichtman, M.K.; Gattinoni, L.; Theoret, M.R.; Grewal, N.; Spiess, P.J.; Antony, P.A.; Palmer, D.C.; et al. IL-15 enhances the in vivo antitumor activity of tumor-reactive CD8 ${ }^{+}$T cells. Proc. Natl. Acad. Sci. USA 2004, 101, 1969-1974.

82. Zhang, M.; Ju, W.; Yao, Z.; Yu, P.; Wei, B.-R.; Simpson, R.M.; Waitz, R.; Fassò, M.; Allison, J.P.; Waldmann, T.A. Augmented IL-15R $\alpha$ expression by CD40 activation is critical in synergistic CD8 T cell-mediated antitumor activity of anti-CD40 antibody with IL-15 in TRAMP-C2 tumors in mice. J. Immunol. 2012, 188, 6156-6164.

83. Vincent, M.; Bessard, A.; Cochonneau, D.; Teppaz, G.; Solé, V.; Maillasson, M.; Birklé, S.; Garrigue-Antar, L.; Quéméner, A.; Jacques, Y. Tumor targeting of the IL-15 superagonist RLI by an anti-GD2 antibody strongly enhances its antitumor potency. Int. J. Cancer 2013, 133, 757-765.

84. Yu, P.; Steel, J.C.; Zhang, M.; Morris, J.C.; Waldmann, T.A. Simultaneous Blockade of multiple immune system inhibitory checkpoints enhances antitumor activity mediated by interleukin-15 in a murine metastatic colon carcinoma model. Clin. Cancer Res. 2010, 16, 6019-6028.

85. Yang, S.; Ji, Y.; Gattinoni, L.; Zhang, L.; Yu, Z.; Restifo, N.P.; Rosenberg, S.A.; Morgan, R.A. Modulating the differentiation status of ex vivo-cultured anti-tumor $\mathrm{T}$ cells using cytokine cocktails. Cancer Immunol. Immunother. 2013, 62, 727-736.

86. Sneller, M.C.; Kopp, W.C.; Engelke, K.J.; Yovandich, J.L.; Creekmore, S.P.; Waldmann, T.A.; Lane, H.C. IL-15 administered by continuous infusion to rhesus macaques induces massive expansion of $\mathrm{CD}^{+} \mathrm{T}$ effector memory population in peripheral blood. Blood 2011, 118, 6845-6848.

87. Waldmann, T.A.; Lugli, E.; Roederer, M.; Perera, L.P.; Smedley, J.V.; Macallister, R.P.; Goldman, C.K.; Bryant, B.R.; Decker, J.M.; Fleisher, T.A.; et al. Safety (toxicity), pharmacokinetics, immunogenicity, and impact on elements of the normal immune system of recombinant human IL-15 in rhesus macaques. Blood 2011, 117, 4787-4795. 
88. Lugli, E.; Mueller, Y.M.; Lewis, M.G.; Villinger, F.; Katsikis, P.D.; Roederer, M. IL-15 delays suppression and fails to promote immune reconstitution in virally suppressed chronically SIV-infected macaques. Blood 2011, 118, 2520-2529.

89. Nugeyre, M.T.; Monceaux, V.; Beq, S.; Cumont, M.C.; Ho Tsong Fang, R.; Chene, L.; Morre, M.; Barre-Sinoussi, F.; Hurtrel, B.; Israel, N. IL-7 stimulates T cell renewal without increasing viral replication in simian immunodeficiency virus-infected macaques. J. Immunol. 2003, 171, 4447-4453.

90. Beq, S.; Nugeyre, M.T.; Ho Tsong Fang, R.; Gautier, D.; Legrand, R.; Schmitt, N.; Estaquier, J.; Barre-Sinoussi, F.; Hurtrel, B.; Cheynier, R.; et al. IL-7 induces immunological improvement in SIV-infected rhesus macaques under antiviral therapy. J. Immunol. 2006, 176, 914-922.

91. Sereti, I.; Dunham, R.M.; Spritzler, J.; Aga, E.; Proschan, M.A.; Medvik, K.; Battaglia, C.A.; Landay, A.L.; Pahwa, S.; Fischl, M.A.; et al. IL-7 administration drives T cell-cycle entry and expansion in HIV-1 infection. Blood 2009, 113, 6304-6314.

92. Parmigiani, A.; Pallin, M.F.; Schmidtmayerova, H.; Lichtenheld, M.G.; Pahwa, S. Interleukin-21 and cellular activation concurrently induce potent cytotoxic function and promote antiviral activity in human CD8 T cells. Hum. Immunol. 2011, 72, 115-123.

93. Chevalier, M.F.; Julg, B.; Pyo, A.; Flanders, M.; Ranasinghe, S.; Soghoian, D.Z.; Kwon, D.S.; Rychert, J.; Lian, J.; Muller, M.I.; et al. HIV-1-specific interleukin-21 ${ }^{+} \mathrm{CD} 4^{+} \mathrm{T}$ cell responses contribute to durable viral control through the modulation of $\mathrm{HIV}$-specific $\mathrm{CD} 8^{+} \mathrm{T}$ cell function. J. Virol. 2011, 85, 733-741.

94. Pallikkuth, S.; Rogers, K.; Villinger, F.; Dosterii, M.; Vaccari, M.; Franchini, G.; Pahwa, R.; Pahwa, S. Interleukin-21 administration to rhesus macaques chronically infected with simian immunodeficiency virus increases cytotoxic effector molecules in T cells and NK cells and enhances B cell function without increasing immune activation or viral replication. Vaccine 2011, 29, 9229-9238.

95. Scripture-Adams, D.D.; Brooks, D.G.; Korin, Y.D.; Zack, J.A. Interleukin-7 induces expression of latent human immunodeficiency virus type I with minimal effects on T-cell phenotype. J. Virol. 2002, 76, 13077-13082.

96. Vandergeeten, C.; DaFonseca, S.; Fromentin, R.; Sekaly, R.; Chomont, N. Differential impact of IL-7 and IL-15 on HIV reservoir persistence. In Final Program and Abstracts of the 5th International Workshop on HIV Pesistence during Therapy; St Maarten, West Indies, 6-9 December 2011.

97. Vandergeeten, C.; Fromentin, R.; Dafonseca, S.; Lawani, M.B.; Sereti, I.; Lederman, M.M.; Ramgopal, M.; Routy, J.P.; Sekaly, R.P.; Chomont, N. Interleukin-7 promotes HIV persistence during antiretroviral therapy. Blood 2013, 121, 4321-4329.

98. Appay, V.; van Lier, R.A.; Sallusto, F.; Roederer, M. Phenotype and function of human T lymphocyte subsets: consensus and issues. Cytometry A 2008, 73, 975-983.

99. Appay, V.; Douek, D.C.; Price, D.A. $\mathrm{CD}^{+} \mathrm{T}$ cell efficacy in vaccination and disease. Nat. Med. 2008, 14, 623-628.

100. Betts, M.R.; Harari, A. Phenotype and function of protective T cell immune responses in HIV. Curr. Opin. HIV/AIDS 2008, 3, 349-355. 
101. Saez-Cirion, A.; Shin, S.Y.; Versmisse, P.; Barre-Sinoussi, F.; Pancino, G. Ex vivo T cell-based HIV suppression assay to evaluate HIV-specific $\mathrm{CD} 8^{+}$T-cell responses. Nat. Protoc. 2010, 5, 1033-1041.

102. Spentzou, A.; Bergin, P.; Gill, D.; Cheeseman, H.; Ashraf, A.; Kaltsidis, H.; Cashin Cox, M.; Anjarwalla, I.; Steel, A.; Higgs, C.; et al. Viral Inhibition Assay: A CD8 T cell neutralization assay for use in clinical trials of HIV-1 vaccine candidates. J. Infect. Dis. 2010, 201, 720-729.

103. Mbitikon-Kobo, F.M.; Bonneville, M.; Sekaly, R.P.; Trautmann, L. Ex vivo measurement of the cytotoxic capacity of human primary antigen-specific CD8 T cells. J. Immunol. Methods 2012, 375, 252-257.

104. Trautmann, L.; Mbitikon-Kobo, F.M.; Goulet, J.P.; Peretz, Y.; Shi, Y.; van Grevenynghe, J.; Procopio, F.A.; Boulassel, M.R.; Routy, J.P.; Chomont, N.; et al. Profound metabolic, functional, and cytolytic differences characterize HIV-specific CD8 T cells in primary and chronic HIV infection. Blood 2012, 120, 3466-3477.

105. Monini, P.; Cafaro, A.; Srivastava, I.K.; Moretti, S.; Sharma, V.A.; Andreini, C.; Chiozzini, C.; Ferrantelli, F.; Cossut, M.R.; Tripiciano, A.; et al. HIV-1 tat promotes integrin-mediated HIV transmission to dendritic cells by binding Env spikes and competes neutralization by anti-HIV antibodies. PLoS One 2012, 7, e48781.

(C) 2013 by the authors; licensee MDPI, Basel, Switzerland. This article is an open access article distributed under the terms and conditions of the Creative Commons Attribution license (http://creativecommons.org/licenses/by/3.0/). 